\title{
PENERAPAN PENDEKATAN PEMBELAJARAN KONTEKSTUAL DALAM PENDIDIKAN AGAMA ISLAM DI UNIVERSITAS PENDIDIKAN INDONESIA
}

\author{
Muhamad Parhan* dan Bambang Sutedja \\ Universitas Pendidikan Indonesia, Bandung \\ *E-mail: parban.muhamad@upi.edu
}

\begin{abstract}
This research is an attempt done by the author in reconstructing learning process to become more fun, focused, fresh, meaningful, and be able to find the essential meaning bebind the theoretical material. The effort made is by applying a contextual learning approach in Islamic religious education that aims to improve student learning outcomes at Universitas Pendidikan Indonesia. This research approach is a combination of quantitative research and qualitative research (mix methods) with the pretest-posttest control group design method. This research proofs that this approach is able to improve student learning outcomes. This can be seen from the achievements of KKM students before treatment by $33.33 \%$ to $82.05 \%$ when treatment has been done. This indicates that the application of contextual learning approach can improve student learning outcomes by $48.72 \%$.
\end{abstract}

Keywords: Learning Approach, Learning, Contextual Learning, Islamic Religious Education

\begin{abstract}
Abstrak. Penelitian ini merupakan sebuah upaya yang dilakukan penulis dalam merekonstruksi pembelajaran agar menjadi lebih fun, focus, fresh, meaningful, serta dapat menemukan makna esensial di balike materi yang teoretikal. Upaya yang dilakukan adalah dengan menerapkan pendekatan pembelajaran kontekstual dalam Pendidikan Agama Islam yang bertujuan untuk meningkatkan hasil belajar mahasiswa di Universitas Pendidikan Indonesia. Pendekatan penelitian ini merupakan kombinasi antara penelitian kuantitatif dan penelitian kualitatif (mix methods) dengan metode pretest-postest cotrol group design. Penelitan ini terbukti dapat meningkatkean hasil belajar mahasiswa, hal ini dapat dilibat dari capaian KKM mahasiswa sebelum dilakukan treatment sebesar 33,33\% menjadi 82,05\% ketika sudab dilakukan treatment, ini menandakan babwa penerapan pendekatan pembelajaran kontekstual dapat meningkatkan hasil belajar mahasiswa sebesar 48,72\%.
\end{abstract}

Kata Kunci: Pendekatan Pembelajaran, Pendekatan Kontekstual, Pendidikan Agama Islam 


\section{PENDAHULUAN}

Pendidikan yang semakin kompleks dan rumit di era revolusi industri 4.0, mengharuskan dunia pendidikan untuk dapat mempersiapkan mahasiswa dalam menghadapi dunia nyata, mahasiswa harus disadarkan pada harapan yang akan mereka capai, tantangan yang akan mereka hadapi, dan kemampuan yang mereka perlu kuasai. Dunia kampus harus bisa menjadi laboratorium kehidupan bagi mahasiswa dalam menghadapi kehidupan riil sehari-harinya, bukan hanya sebagai tempat mencari pendidikan secara formal yang teoretis, akontekstual dan abstrak, yang berupa rutinitas ceremonial keilmuan semata, tanpa berupaya lebih untuk bisa memberi makna dalam setiap proses pembelajarannya.

Kenyataan dalam kebanyakan praktik pendidikan sekarang, pengajaran hanya menonjolkan tingkat hafalan dari materi atau pokok bahasan, tetapi belum diikuti dengan pemahaman dan pengertian yang mendalam untuk bisa diterapkan ketika berhadapan dengan situasi baru dalam kehidupan nyata. Pendidikan yang terjadi di dunia kampus selama ini hanya menterjemahkan pendidikan sebagai transfer of knowledge dari dosen kepada mahasiswa.

Model pendidikan seperti ini oleh Paulo Fraire dikritik sebagai banking education (Fraire, 1970, hlm. 119) yaitu suatu model pendidikan yang tidak kritis, karena hanya diarahkan untuk domestifikasi, penjinakan, penyesuaian sosial dengan keadaan penindasan. Model pendidikan seperti ini hanya berfungsi untuk mematikan kreativitas mahasiswa, karena lebih mengedepankan aspek verbalisme.

Berdasarkan permasalahan tersebut, maka munculah pertanyaan, pendekatan pembelajaran seperti apakah yang dapat digunakan dalam proses pembelajaran PAI? sehingga materi yang disampaikan dapat dirancang untuk menggabungkan pengetahuan dan tindakan, serta pembelajaran menjadi lebih aktual, konkret, realistik, nyata, menyenangkan, dan bermakna.

Solusi dari permasalahan tersebut dapat dipecahkan dengan menerapkan pendekatan pembelajaran kontekstual dalam pembelajarannya. Pembelajaran secara kontekstual melibatkan semua alat indra secara serentak sehingga kegiatan pembelajaran menurut Tafsir (2011, hlm. 6) adalah sebuah usaha meningkatkan diri dalam segala aspeknya, dengan melakukan bimbingan terhadap seluruh asepeknya.

Kesadaran tentang perlunya penerapan pendekatan kontekstual dalam pembelajaran, didasarkan pada kenyataan bahwa sebagian besar mahasiswa masih belum mampu mengaitkan antara apa yang mereka pelajari dengan bagaimana pemanfaatannya dalam kehidupan nyata mereka sehari-hari. Hal ini disebabkan pemahaman konsep akademik yang mereka peroleh hanyalah merupakan sesuatu yang abstrak, belum menyentuh aspek praktis kehidupan mereka, baik di lingkungan kerja maupun di masyarakat.

Hal ini memberikan arti bahwa pembelajaran PAI dengan menggunakan pendekatan kontekstual merupakan solusi bagi penulis sebagai dosen dalam melakukan proses belajarmengajar, supaya hasil belajar mahasiswa dapat meningkat dan menjadi lebih baik, dengan kondisi yang fun, focus, fresh and meaningful dengan mengaitkan antara materi yang disampaikan dengan situasi dunia nyata mahasiswanya, mahasiswa dapat menemukan hubungan penuh makna antara ide-ide abstrak dengan penerapan praktis di dalam konteks kehidupan nyata.

Mahasiswa dapat menginternalisasi konsep, penemuan, penguatan, dan keterhubungan setiap kali proses pembelajaran dilakukan. Pembelajaran mendorong mahasiswa untuk 
mengelaborasi pengetahuan yang dimilikinya dengan penerapan dalam kehidupan nyata.

Pembelajaran yang dilakukan tidak lagi hanya menyampaikan materi (transfer of knowledge) dari dosen terhadap mahasiswa, tetapi proses pembelajaran harus mampu menanamkan sikap (transform of atittude), dan menanamkan nilai-nilai (transform of values). Pembelajaran dengan penerapan pendekatan pembelajaran kontekstual dirancang untuk menggabungkan pengetahuan dan tindakan, kegiatan pembelajaran yang dilakukan lebih konkret, lebih realistik, lebih aktual, lebih nyata, lebih menyenangkan, dan lebih bermakna dengan menemukan makna esensial dibalik materi yang teoretikal.

\section{METODE PENELITIAN}

Pendekatan penelitian ini merupakan kombinasi antara penelitian kuantitatif dan penelitian kualitatif (mix methods) dengan metode true experimental design dengan bentuk pretest-postest control group design. Pendekatan kuantitatif peneliti gunakan untuk menghitung hasil angket kelas eksperiment sebelum dan sesudah dilakukan treatment, serta hasil pre test dan post test. Kemudian pendekatan kuantitatif juga digunakan untuk membedakan hasil pre test dan post test antara kelas kontrol dan kelas eksperiment dengan menggunakan perhitungan statistik yang dapat diukur dan dilihat secara langsung, kemudian disajikan dalam bentuk angkaangka dan gambar serta diagram.

Sementara pendekatan kualitatif digunakan untuk mendeskripsikan dan menganalisis penerapan pendekatan pembelajaran kontekstual yang digunakan dalam mata kuliah PAI. Hal ini dilakukan dengan cara mendeskripsikan dalam bentuk katakata dan bahasa yang menggunakan metode deskriptif-analitik, yaitu dengan cara mengumpulkan data dan menggambarkannya atau memaparkan apa adanya dari hasil penelitian, kemudian disusun dan dituangkan dalam bentuk tulisan (naratif), ditafsirkan dan dianalisis. Sedangkan teknik pengumpulan data dalam penelitian ini adalah observasi, kuesioner berupa angket, dan tes berupa pre test serta post test. Teknik analisis data yaitu reduksi data, display data, dan kesimpulan/verifikasi.

Untuk analisis data kuantitatif peneliti akan menggunakan nonparametrik test dengan uji wilcoxon, hal ini dilakukan karena data penelitian tidak berdistribusi normal. Uji wilcoxon digunakan untuk membandingkan dan membuktikan apakah ada perbedaan yang signifikan antara pembelajaran sebelum dan sesudah menggunakan penerapan pendekatan pembelajaran kontekstual dengan menghitung hasil pre test dan post test.

Dalam tahap observasi, peneliti melakukan penelitian pendahuluan dengan menganalisis komponenkomponen pembelajaran kontekstual yang diterapkan dalam pembelajaran pendidikan agama Islam. kemudian dibuat angket tentang komponenkomponen pendekatan pembelajaran kontekstual tersebut. Untuk kemudian di lihat hasil sebelum dan sesudah dilakukan treatment.

Pada penelitian ini dilakukan sebanyak dua kali yaitu sebelum treatmennt (pre test) dan sesudah dilakukan treatment (post test). Untuk melihat tingkat efektivitas dari penerapan pendekatan pembelajaran kontekstual maka dilakukan pengukuran dengan pre test dan post test pada kelas ekesperiment. Selain itu, dilakukan perbandingan antara kelas kontrol dengan kelas eksperiment. Kelas kontrol dengan menggunakan pendekatan ceramah, dan diskusi, sedangkan kelas eksperiment dengan 
menggunakan pendekatan pembelajaran kontekstual.

Penelitain ini dilakukan di Universitas Pendidikan Indonesia Jl. Dr. Setiabudi No. 229, Isola, Kec. Sukasari, Kota Bandung. Lokasi ini dipilih dikarenakan peneliti sendiri sebagai dosen pengampu mata kuliah PAI di kampus tersebut, yang mempunyai kewajiban akademis untuk meningkatkan hasil pembelajaran bagi mahasiswa di kampus dimana peneliti bertugas.

\section{HASIL PENELITIAN DAN PEMBAHASAN}

Penerapan pendekatan pembelajaran kontestual dalam pembelajaran PAI di perguruan tinggi harus dilihat ketercapaian dari komponen-komponen pembelajaran dengan pendekatan kontekstual. Dari hasil angket penelitian, terlihat bahwa ada peningkatan ketercapaian komponenkomponen pembelajaran antara proses pembelajaran sebelum dan sesudah menerapkan pendekatan pembelajaran kontekstual, hal itu dapat dilihat seperti di bawah ini:

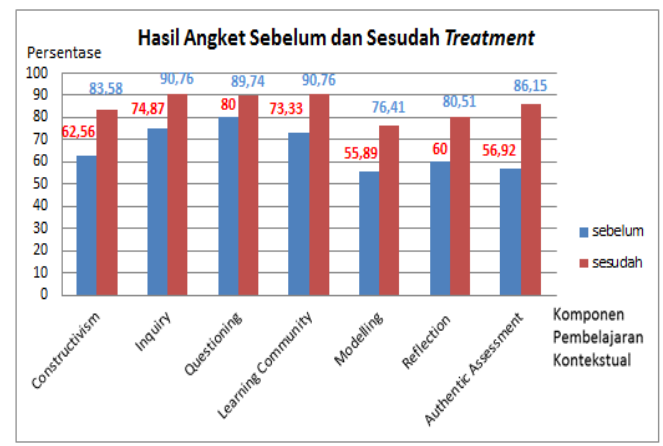

Gambar 1. Hasil angket sebelum dan sesudah menggunakan pendekatan pembelajaran kontekstual

Adapun komponen-komponen tersebut setidaknya harus memiliki tujuh asas (komponen). Komponen-komponen ini melandasi pelaksanaan proses pembelajaran dengan menggunakan pendekatan kontekstual. Seringkali komponen ini disebut juga unsur atau asas yang harus ada di dalam pembelajaran kontekstual, komponen-komponen tersebut adalah seperti yang dikemukakan di bawah ini:

\section{a. Konstruktivisme (constructivism)}

Konstruktivisme adalah proses membangun atau menyusun pengetahuan baru dalam struktur kognitif mahasiswa berdasarkan pengalaman (Hamruni, 2012, hlm. 142). Pengetahuan dibangun oleh manusia sedikit demi sedikit, yang hasilnya diperluas melalui konteks yang terbatas (sempit) dan tidak sekonyong-konyong. Pengetahuan bukanlah seperangkat faktafakta, konsep atau kaidah yang siap untuk diambil dan diingat (Komalasari, 2013, hlm. 11).

Manusia harus mengkonstruksi pengetahuan itu dan memberi makna melalui pengalaman nyata. Pengetahuan itu memang berasal dari luar, akan tetapi dikonstruksi oleh dan dari dalam diri seseorang. Pengetahuan dibangun melalui pemahaman mahasiswa dari pengalaman baru berdasarkan pengetahuan awal, dan pembelajaran harus dikemas menjadi proses mengkonstruksi bukan hanya menerima pengetahuan (Aqib, 2013, hlm. 7).

Oleh sebab itu, pengetahuan terbentuk oleh dua faktor penting, yaitu objek yang menjadi bahan pengamatan dan kemampuan subjek untuk menginterpretasi objek tersebut. Kedua faktor itu sama pentingnya, dengan demikian pengetahuan itu tidak bersifat statis tetapi bersifat dinamis, tergantung individu yang melihat dan mengkonstruksinya.

Asumsi itu yang kemudian melandasi pembelajaran kontekstual. Pembelajaran melalui pendekatan kontekstual pada dasarnya mendorong agar mahasiswa bisa mengkonstruksi pengetahuannya melalui proses pengamatan dan pengalaman. Hal ini karena pengetahuan hanya akan fungsional manakala dibangun oleh individu. Pengetahuan yang hanya 
diberikan tidak akan menjadi pengetahuan yang bermakna. Atas dasar asumsi yang mendasari itulah, maka penerapan asas konstruktivisme dalam pembelajaran melalui pendekatan kontekstual, mahasiswa didorong untuk mampu mengkonstruksi pengetahuan sendiri melalui pengalaman nyata (Sanjaya, 2010, hlm. 265).

Dengan pengalaman nyata yang mahasiswa lakukan, maka nilai-nilai akademisi menjadi lebih bermakna dan lebih riil, sehingga nilai-nilai akademis tersebut dapat menjadi nilai-nilai yang diaplikasikan dalam kehidupannya. Karena nilai-nilai hidup itu adalah didapatkan, bukan hanya diajarkan (Lickona, 2013, hlm. 118).

\section{b. Menemukan (Inquiry)}

Menemukan (inquiry) berarti proses pembelajaran didasarkan pada pencarian dan penemuan melalui proses berpikir secara sistematis. Pengetahuan bukanlah sejumlah fakta hasil mengingat akan tetapi hasil dari proses menemukan sendiri. Dengan demikian dalam proses pembelajaran dosen bukanlah mempersiapkan sejumlah materi yang harus dihapal, akan tetapi merancang pembelajaran, memfasilasi, dan mengarahkan mahasiswa agar dapat menemukan sendiri materi yang harus dipahaminya.

Belajar pada dasarnya merupakan proses mental seseorang yang tidak terjadi secara mekanis. Melalui proses mental itulah, diharapkan mahasiswa berkembang secara utuh, baik intelektualnya, mental, emosional, maupun pribadinya (Sanjaya, 2010, hlm. 265). Pembelajaran dilakukan melalui proses perpindahan dari pengamatan menjadi pemahaman dengan mengajak mahasiswa untuk belajar menggunakan keterampilan berpikir secara kritis (Aqib, 2013, hlm. 7).

Mengenai asas pembelajaran kontekstual dengan menemukan (inquiry) (Komalasari, 2013, hlm. 12), menjelaskan bahwa: Pengetahuan dan keterampilan yang diperoleh diharapkan bukan hasil dari mengingat seperangkat fakta-fakta, melainkan menemukan sendiri melalui siklus: (1) observasi (observation), (2) bertanya (questioning), (3) mengajukan dugaan (bypothesis), (4) mengumpulkan data (data gathering), dan penyimpulan (conclusion). Berbagai topik dalam setiap mata kuliah dapat dilakukan melalui proses inquiry, termasuk dalam proses pembelajaran pendidikan agama Islam. Secara umum proses inquiry dapat dilakukan melalui beberapa langkah, yaitu: (1) merumuskan masalah, (2) mengajukan hipotesis, (3) mengumpulkan data, (4) menguji hipotesis berdasarkan data yang ditemukan, dan (5) membuat kesimpulan (Hamruni, 2012, hlm. 143). Penerapan asas menemukan (inquiry) dalam pembelajaran kontekstual dimulai dari adanya kesadaran mahasiswa terhadap masalah yang jelas yang ingin dipecahkan.

Dengan demikian, mahasiswa didorong untuk menemukan masalah. Jika masalah telah dipahami dengan batasanbatasan yang jelas, selanjutnya mahasiswa dapat mengajukan hipotesis atau jawaban sementara sesuai dengan rumusan masalah yang diajukan. Hipotesis itulah yang menuntun mahasiswa untuk dapat melakukan observasi dalam rangka mengumpulkan data. Manakala data telah terkumpul, selanjutnya mahasiswa dituntun untuk menguji hipotesis sebagai dasar dalam merumuskan kesimpulan.

\section{c. Bertanya (Questioning)}

Belajar pada hakikatnya adalah bertanya dan menjawab pertanyaan. Bertanya dapat dipandang sebagai refleksi dari keingintahuan setiap individu, sedangkan menjawab pertanyaan mencerminkan kemampuan seseorang dalam berpikir (Sanjaya, 2010, hlm. 266).

Bertanya (questioning) bagi dosen merupakan kegiatan untuk mendorong, membimbing dan minilai kemampuan berpikir mahasiswanya, dan bagi 
mahasiswa hal ini merupakan bagian penting dalam pembelajaran guna menggali informasi yang ingin diketahuinya (Aqib, 2013, hlm. 7). Dalam pembelajaran kontekstual, dosen tidak menyampaikan informasi begitu saja, tetapi memancing agar mahasiswa dapat menemukan sendiri. Karena itu peran bertanya menjadi sangat penting, sebab melalui pertanyaan-pertanyaan dosen dapat membimbing dan mengarahkan mahasiswa untuk menemukan setiap materi yang dipelajarinya (Hamruni, 2012, hlm. 144).

Pengetahuan yang dimiliki seseorang selalu bermula dari bertanya, bagi dosen bertanya dipandang sebagai kegiatan untuk mendorong, membimbing, dan menilai kemampuan berpikir mahasiswanya. Banyak terjadi di dalam kelas dimana dosen bertanya dan mahasiswa mencoba untuk menjawab, ataupun dosen memfasilitasi sesama mahasiswa untuk saling bertanya dan menjawab pertanyaan yang diajukan.

Dalam suatu pembelajaran yang produktif kegiatan bertanya akan sangat berguna untuk: (1) menggali informasi tentang kemampuan mahasiswa dalam penguasaan materi pelajaran, (2) membangkitkan motivasi mahasiswa untuk belajar, (3) merangsang keingintahuan mahasiswa terhadap materi yang disampaikan, (4) memfokuskan mahasiswa terhadap sesuatu yang diinginkan, dan (5) membimbing mahasiswa untuk menemukan atau menyimpulkan sesuatu. Dalam setiap tahapan dan proses pembelajaran kegiatan bertanya hampir selalu digunakan. Karena itu, kemampuan dosen untuk mengembangkan teknik-teknik bertanya sangat diperlukan (Hamruni, 2012, hlm. 144-145).

\section{d. Masyarakat Belajar (Learning Community)}

Hasil pembelajaran diperoleh dari kerja sama dengan orang lain. Dosen disarankan selalu melaksanakan pembelajaran dan memfasilitasi mahasiswa untuk membentuk kelompok-kelompok belajar, dalam mengelaborsi materi yang diberikan, pengetahuan dan pemahaman mahasiswa ditopang banyak oleh komunikasi dengan orang lain.

Suatu permasalahan tidak mungkin dapat dipecahkan sendirian, tetapi membutuhkan bantuan orang lain. Kerja sama saling memberi dan menerima sangat dibutuhkan untuk memecahkan suatu persoalan, konsep masyarakat belajar (learning community) dalam pembelajaran kontekstual menyarankan agar hasil pembelajaran diperoleh melalui kerja sama dengan orang lain.

Kerja sama itu dapat dilakukan dalam berbagai bentuk, baik dalam kelompok belajar secara formal maupun dalam lingkungan yang terjadi secara alamiah. Hasil belajar dapat diperoleh dari hasil sharing dengan orang lain, antar teman, antar kelompok, yang sudah tahu memberi tahu kepada yang belum tahu, yang pernah memiliki pengalaman membagi pengalamannya pada orang lain. Inilah hakikat dari masyarakat belajar, yaitu masyarakat yang saling berbagi (Sanjaya, 2010, hlm. 267).

Masyarakat belajar (learning community) menurut (Lickona, 2013, hlm. 157), sangat berguna dalam: Memupuk sebuah rasa kebersamaan di dalam sebuah kelompok, yang merupakan aspek dasar dari kebersamaan komunitas di dalam kelas. Ada tiga hal yang berkontribusi terhadap aspek komunitas ini: (1) kelas tersebut memiliki sebuah identitas kelompok, (2) setiap individu merasa bahwa dia merupakan seorang anggota yang berguna di dalam kelompoknya, dan (3) setiap individu merasa bertanggung jawab terhadap kelompoknya.

Kegiatan belajar secara berkelompok menitikberatkan terhadap kerja sama antara mahasiswa yang satu dengan peserta didik yang lain, dengan cara saling bertukar pengalaman dan berbagi ide, yang 
melibatkan semua mahasiswa yang terikat dalam kegiatan belajar (Aqib, 2013, hlm. 7). Kerja sama dalam pembelajaran yang dilakukan merupakan kerja sama dalam konteks saling tukar pikiran, mengajukan dan menjawab pertanyaan, kumunikasi interaktif antar sesama mahasiswa, antara mahasiswa dengan dosen, antara mahasiswa dengan narasumber, untuk memecahkan masalah dan mengerjakan tugas bersama dengan menghargai perbedaan pemikiran, ide, dan konsep yang diajukan dari setiap anggota kelompok.

Dalam pembelajaran kontekstual, penerapan asas masyarakat belajar (learning community) dapat dilakukan dengan menerapkan pembelajaran melalui kelompok belajar. Mahasiswa dibagi dalam kelompok-kelompok yang anggotanya bersifat heterogen, baik dilihat dari kemampuan dan kecepatan belajarnya, maupun dari bakat dan minatnya. Biarkan dalam kelompoknya mereka saling belajar, yang cepat belajar didorong untuk membantu yang lambat belajar, yang memiliki kemampuan tertentu didorong untuk menularkannya pada yang lain (Hamruni, 2012, hlm. 145).

\section{e. Pemodelan (Modelling)}

Asas pemodelan (modelling) adalah proses pembelajaran dengan memperagakan sesuatu dengan contoh yang dapat ditiru oleh setiap mahasiswa. Asas pemodelan (modelling) merupakan sebuah proses penampilan suatu contoh agar mahasiswa dapat berpikir, bekerja dan belajar (Aqib, 2013, hlm. 7).

Dalam pembelajaran keterampilan atau pengetahuan tertentu ada model yang bisa ditiru. Dosen dapat menjadi model, tetapi dosen bukan satu-satunya model, artinya model dapat dirancang dengan melibatkan mahasiswa, misalnya mahasiswa ditunjuk untuk menjadi dan memberi contoh pada temannya, atau mendatangkan seseorang di luar lingkungan kampus.
Pemodelan (modelling) merupakan asas yang cukup penting dalam pembelajaran kontekstual, sebab melalui pemodelan (modelling) mahasiswa dapat terhindar dari pembelajaran yang teoretis-abstrak yang memungkinkan terjadinya verbalisme (Sanjaya, 2010, hlm. 267-268).

\section{f. Refleksi (Reflection)}

Refleksi (reflection) adalah proses pengendapan pengalaman yang telah dipelajari yang dilakukan dengan cara mengurutkan kembali kejadian-kejadian atau peristiwa pembelajaran yang telah dilaluinya (Sanjaya, 2010, hlm. 268). Melalui proses refleksi (reflection), pengalaman belajar itu akan dimasukan dalam struktur kognitif mahasiswa yang pada akhirnya akan menjadi bagian dari pengetahuan yang dimilikinya. Bisa terjadi melalui proses refleksi mahasiswa akan memperbaharui pengetahuan yang telah dibentuknya, atau menambah khazanah pengetahuannya (Hamruni, 2012, hlm. 146-147).

Dalam pembelajaran kontekstual dengan asas refleksi (reflection) dosen menggiring mahasiswa untuk berpikir tentang apa yang baru dipelajari atau berpikir kebelakang tentang apa-apa yang sudah dilakukan dimasa lalu. Mahasiswa mengedepankan apa yang baru dipelajarinya sebagai struktur pengetahuan yang baru, yang merupakan pengayaan atau revisi dari pengetahuan sebelumnya.

Biarkan secara bebas mahasiswa menafsirkan pengalaman belajarnya sendiri, sehingga ia dapat menyimpulkan tentang pengalaman belajarnya. Metode ini sebagai induksi yang menjadikan mahasiswa bisa mengapresiasi pada tingkatan intelektual dan emosional.

\section{g. Penilaian Nyata (Authentic Assessment)}

Kemajuan belajar dinilai dari proses, bukan semata hasil, dan dengan berbagai cara. Penilaian dapat berupa penilaian tertulis (pencil and paper test) dan penilaian 
berdasarkan perbuatan (performance based assessment), penugasan (project), produk (product), atau portofolio (Komalasari, 2013, hlm. 13). Proses pembelajaran konvensional yang sering dilakukan dosen pada saat ini biasanya ditekankan kepada perkembangan aspek intelektualnya saja, sehingga alat evaluasi yang digunakan terbatas pada penggunaan tes. Dengan tes dapat diketahui seberapa jauh mahasiswa telah mengetahui dan menguasai materi pelajaran (Sanjaya, 2010, hlm. 268).

Dalam pembelajaran kontekstual, keberhasilan pembelajaran tidak hanya ditentukan oleh tes yang hanya mengukur perkembangan kemampuan intelektual saja, tetapi penilaian diarahkan kepada perkembangan seluruh aspek, baik itu kognitif, afektif, maupun psikomotor mahasiswa.

Penilaian nyata (authentic assessment) adalah proses yang dilakukan dosen untuk mengumpulkan informasi tentang perkembangan belajar yang dilakukan mahasiswanya. Penilaian ini diperlukan untuk mengetahui apakah mahasiswa benar-benar belajar atau tidak, apakah pengalaman belajar mahasiswa memiliki pengaruh yang positif terhadap perkembangan mereka, baik perkembangan intelektual maupun mental mereka.

Penilaian ini dilakukan untuk mengukur pengetahuan dan keterampilan mahasiswa yang lebih berorientasi pada penilaian kinerja serta tugas-tugas yang relevan dan kontekstual (Aqib, 2013, hlm. 8). Penilaian nyata (authentic assessment) dilakukan secara terintegrasi dengan proses pembelajaran. Penilaian ini dilakukan secara terus-menerus selama kegiatan pembelajaran berlangsung. Oleh sebab itu, tekanannya diarahkan kepada proses belajar bukan kepada hasil belajar. Pembelajaran yang menerapkan konsep authentic assessment adalah pembelajaran yang mengukur, memonitor, dan menilai semua aspek hasil belajar (yang tercakup dalam domain kognitif, afektif, dan psikomotor), baik yang tampak sebagai hasil akhir dari suatu proses pembelajaran maupun berupa perubahan dan perkembangan aktivitas dan perolehan belajar selama proses pembelajaran di dalam kelas ataupun di luar kelas.

Dengan demikian penilaian pembelajaran untuk menyeluruh dalam aspek kognitif, afektif, dan psikomotor, serta dalam keseluruhan tahapan proses pembelajaran (di awal, tengah, dan akhir). Disamping itu, penilaian tidak hanya diserahkan pada dosen, tetapi mahasiswa pun dapat melakukan penilaian terhadap mahasiswa yang lain, serta mereka diarahkan untuk dapat melakukan penilaian terhadap dirinya sendiri (selfevaluation) dalam aktivitas pembelajaran dan pemahaman materi.

Untuk melihat tingkat efektivitas dari penerapan pendekatan pembelajaran kontekstual dalam mata kuliah PAI, maka harus disajikan data-data sebelum dilakukan treatment berupa hasil pre test dan data-data setelah dilakukan treatment berupa hasil post test. hal ini dilakukan agar perubahan hasil pembelajaran dapat terukur melalui data dan angka. Adapun hasilnya dapat di lihat seperti di bawah ini:

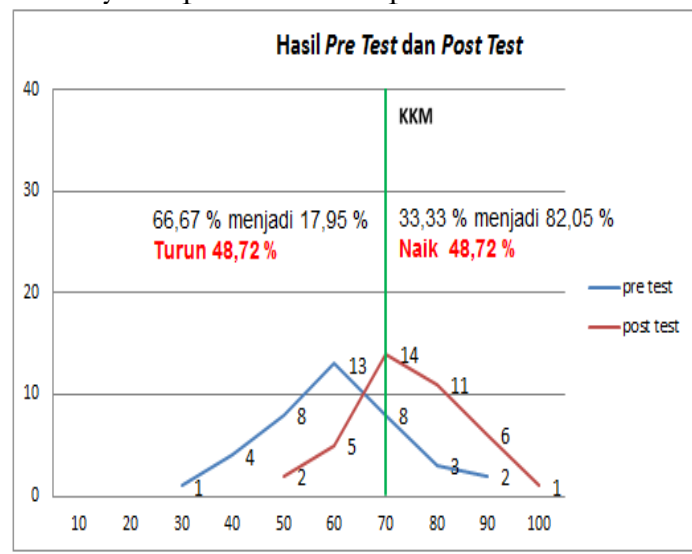

Gambar 2. Hasil pre test dan post test kelas eksperiment

Dari hasil penghitungan pre test dan post test dapat diketahui bahwa ketercapaian nilai mahasiswa yang sudah mencapai KKM (Kriteria Ketuntasan Minimal) atau nilai batas ambang 
kompetensi sebelum dilakukan treatment sebesar 33,33\% dan sisanya sebanyak $66,67 \%$ mahasiswa masih belum mencapai KKM, sementara setelah dilakukan treatment dengan penerapan pendekatan pembelajaran kontekstual, hasil capaian KKM mahasiswa meningkat menjadi $82,05 \%$.

Ini artinya ada peningkatan hasil belajar mahasiswa dari 33,33\% menjadi $80,05 \%$ yang menandakan bahwa penerapan pendekatan pembelajaran kontekstual dapat meningkatkan hasil belajar mahasiswa sebesar $48,72 \%$, serta dengan penerapan model pembelajaran kontekstual mahasiswa dapat menemukan makna esensial di balik materi yang teoretikal.

Sementara untuk melihat tingkat efektivitas dengan kelas kontrol dapat di lihat seperti di bawah ini:

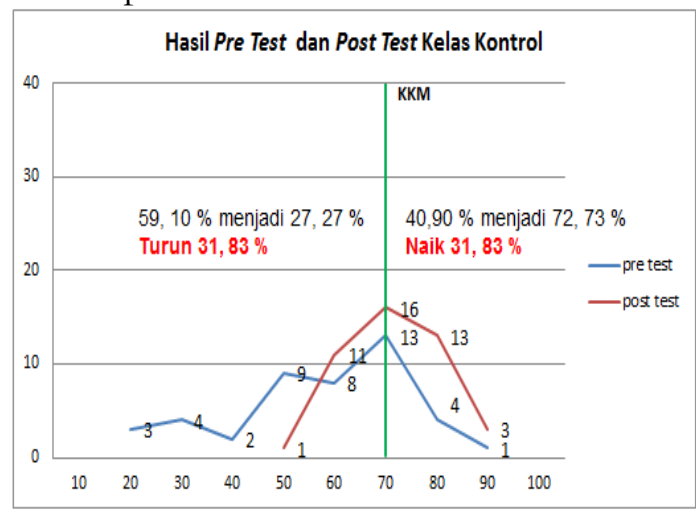

Gambar 3. Hasil pre test dan post test kelas kontrol

Hasil pre test kelas kontrol yang mencapai KKM sebanyak 40,90 \% mahasiswa, dan yang belum mencapai KKM sebanyak 59,10 \%, dan ketika diberikan post test, terdapat perubahan terhadap capaian KKM, dari 40, 90 \% menjadi $72,73 \%$ dan yang belum mencapai KKM turun dari 59,20 \% menjadi 27,27 \%, ini artinya kelas kontrol naik sebesar 31, $83 \%$. Ketika dibandingkan dengan kelas yang melakukan pembelajaran dengan penerapan pendekatan kontekstual terlihat perbedaan yang jelas antara capaian KKM yang di dapat. Kelas eksperiment naik sebesar 48, $72 \%$ dan kelas kontrol naik 31, $83 \%$. Ini artinya bahwa kelas eksperiment yang melakukan proses pembelajaran dengan pendekatan kontekstual hasilnya lebih besar dari kelas kontrol. Hal ini menandakan bahwa penerapan pendekatan pembelajaran kontekstual dalam mata kuliah PAI dapat meningkatkan hasil belajar mahasiswa, sehingga hasil belajar mahasiswa menjadi lebih baik.

Berdasarkan uji statistik diperoleh hasil seperti di bawah ini:

\begin{tabular}{|c|c|c|c|c|c|c|c|}
\hline & \multirow[b]{2}{*}{ kelas } & \multicolumn{3}{|c|}{ Kolmogorov-Sminovi } & \multicolumn{3}{|c|}{ Shapiro-Wilk } \\
\hline & & Statistic & df & Sig. & Statisitic & df & Sig. \\
\hline \multirow[t]{4}{*}{ hasil penelitian } & pre test teksperiment & ,174 & 39 & ,004 & .951 & 39 & ,088 \\
\hline & post test eksperiment & , 187 & 39 & ,001 & 934 & 39 & ,024 \\
\hline & pre test kontrol & 177 & 44 & 001 & .924 & 44 & .006 \\
\hline & post test kontrol & 193 & 44 & .000 & 901 & 44 & .00 \\
\hline
\end{tabular}

Gambar 4. Uji normalitas data

Berdasarkan hasil penghitungan di atas, diketahui nilai signifikansi (Sig) dari kolmogrov psminov dan shapiro-wilk ada sebagian data yang $>0,05$ maka dapat disimpulkan hasil penelitian tidak berdistribusi normal. Karena data penelitian tidak berdistribusi normal maka dapat dilakukan perhitungan uji wilcoxon untuk melakukan penghitungan data penelitian.

Dari hasil nonparametrik test dengan uji wilcoxon diperoleh hasil seperti berikut:

\begin{tabular}{|c|c|c|c|c|}
\hline \multicolumn{5}{|c|}{ Ranks } \\
\hline & & $\mathrm{N}$ & Mean Rank & Sum of Ranks \\
\hline post test treatment- pre test & Negative Ranks & $1^{a}$ & 9,50 & 9,5 \\
\hline treatment & Positive Ranks & $31^{\circ}$ & 16,73 & 518,5 \\
\hline & Ties & $7^{\circ}$ & & \\
\hline & Total & 39 & & \\
\hline \multicolumn{5}{|c|}{ Test Statistics ${ }^{\mathrm{a}}$} \\
\hline & & \multicolumn{3}{|c|}{$\begin{array}{c}\text { post test } \\
\text { treatment - pre } \\
\text { test treatment } \\
\end{array}$} \\
\hline$z$ & & \multicolumn{3}{|c|}{$-4,873^{\circ}$} \\
\hline Asymp. Sig. (2 & 2-tailed) & \multicolumn{3}{|r|}{, 000} \\
\hline
\end{tabular}
a. Wilcoxon Signed Ranks Test
b. Based on negative ranks.

Gambar 5. Uji Wilcoxon 
Dari hasil penghitungan statistik di atas diketahui bahwa penerapan pendekatan pembelajaran kontekstual pada kelas yang dilakukan treatment terdapat 1 orang mahasiswa yang mengalami penurunan hasil belajar dan 7 orang mahasiswa mendapatkan nilai yang sama, dan sisanya sebanyak 31 orang mahasiswa hasil belajarnya meningkat, dengan rata-rata peningkatan sebesar 16,73 dengan jumlah ranking atau sum of rank sebesar 518, 50. Berdasarkan test statistik Asymp. Sig. (2-tailed) bernilai $0,000<0,05$ maka dapat disimpulkan bahwa ada pengaruh peningkatan hasil belajar mahasiswa dengan penerapan pendekatan pembelajaran kontekstual dalam mata kuliah PAI di Universitas Pendidikan Indonesia.

Hal ini bisa dilihat dari banyaknya mahasiswa yang mengalami peningkatan hasil belajar, yang berjumlah 31 orang. Dapat dikatakan bahwa sebagian besar mahasiswa telah berhasil dalam proses belajar-mengajar yang telah dilakukan. Sehingga penerapan pendekatan pembelajaran dengan pendekatan kontekstual secara umum dapat meningkatkan sejumlah besar (mayoritas) mahasiswa dalam mencapai hasil pembelajaran yang lebih baik.. Hasil pembelajaran menunjukan sebesar 48, $72 \%$ kelas eksperiment mengalami kenaikan, sedangkan kelas kontrol mengalami kenaikan sebesar 31, $83 \%$, ini berarti kelas eksperiment lebih baik dibandingkan dengan kelas kontrol.

Pembelajaran dengan pendekatan kontekstual dapat lebih baik dibandingkan dengan kelas kontrol, dikarenakan proses pembelajaran pendidikan agama Islam menekankan konsep belajar-mengajar yang membantu dosen (sebagai pendidik) untuk mengaitkan antara materi yang diajarkan dengan situasi dunia nyata mahasiswa, dan mendorongnya untuk membuat hubungan antara pengetahuan yang dimiliki dengan penerapan dalam kehidupan mereka sehari-hari. Hal ini memberikan arti bahwa dosen dapat berperan menjadi fasilitator kepada mahasiswa agar dapat menemukan hubungan penuh makna antara ide-ide abstrak dengan penerapan praktis di dalam konteks kehidupan nyata.

Mahasiswa dapat menginternalisasi konsep, penemuan, penguatan, dan keterhubungan setiap kali proses pembelajaran dilakukan. Karena pengetahuan dikatakan akurat ketika pengetahuan itu mencerminkan realitas. Oleh sebab itu, pembelajaran bukan sebuah cerminan dari dunia luar yang diperoleh melalui pengamatanpengamatan saja, tetapi harus melibatkan interaksi-interaksi mahasiswa dengan merepresentasikan pengetahuan dari dunia luar melalui pengalamanpengalaman, pengamatan terhadap model-model, dan pengajaran. Materi pengetahuan menurut (Schunk, 2012, hlm. 232) dikatakan bahwa:

The acquisition of knowledge represents a reconstruction of the external world. The world influences beliefs through experiences, exposure to models, and teaching. Knowledge is accurate to the extent it reflects external reality. This view posits a strong influence ot the external world on knowledge construction, such as by experiences, teaching, an exposure to models.

Pembelajaran mendorong mahasiswa agar dapat mengelaborasi pengetahuan yang dimiliki dengan penerapan nyata dalam kehidupan sehari-hari mereka. Hal ini sejalan dengan Jhonson (2002, hlm. 24) "Contextual teaching and learning enables to connect the content of academic subjects the immadiate context of their daily lives to discover meaning". Johnson menjelaskan bahwa pembelajaran kontekstual merupakan pendekatan pembelajaran yang berupaya agar mahasiswa dapat mengaitkan antara materi yang diterimanya dengan konteks kehidupan 
sehari-hari mereka, hal ini dilakukan agar materi pelajaran yang diterima, dapat lebih bermakna bagi kehidupannya.

Penerapan pembelajaran kontekstual dalam pendidikan agama Islam menekankan bahwa mahasiswa belajar dengan cara mengkonstruk pengetahuan dan keterampilan barunya, pembelajaran dipersepsi untuk menghadirkan relevansi dengan kehidupan nyata, melakukan kegiatan pemecahan masalah untuk menemukan makna dalam keragaman kebermaknaan, mengembangkan sifat ingin tahu dengan bertanya, menciptakan masyarakat belajar, sehingga mahasiswa menjadi manusia pembelajar sepanjang hayat. Kemudian menghadirkan model sebagai contoh pembelajaran.

Dosen dan orang dewasa di sekeliling mahasiswa menjadi model yang sangat efektif dalam pembelajaran ini. Melakukan refleksi dalam setiap akhir pembelajaran untuk menguatkan bangunan pengalaman yang diterima mahasiswa dan melakukan penilaian dengan berbagai cara untuk mendapatkan hasil belajar yang sesungguhnya.

Dengan demikian, kegiatan pembelajaran akan lebih konkret, lebih realistik, lebih aktual, lebih nyata, lebih menyenangkan, dan lebih bermakna. Kegiatan pembelajaran dapat meningkatkan hasil belajar yang lebih berkualitas, lebih mendorong timbulnya kreativitas dan produktivitas serta efisiensi dengan dikonstruk sendiri oleh mahasiswa dalam setiap kali proses pembelajan. Mahasiswa dalam proses pembelajaran harus bisa membangun pengetahuan dalam pikiran mereka sendiri, dan dosen dapat memfasilitasi proses ini dengan mengajar yang menyajikan informasi bermakna dan relevan bagi mahasiswa, serta memberi kesempatan kepada mahasiswa menemukan atau menerapkan sendiri gagasan, kemudian memfasilitasi mahasiswa untuk menggunakan strategi mereka sendiri untuk belajar, dosen dapat memberikan tangga menuju pemahaman yang lebih tinggi kepada mahasiswa, dan mahasiswa sendiri yang harus menaiki tangga tersebut (Slavin, 2011, hlm. 4).

Penerapan

pendekatan pembelajaran kontekstual dalam pendidikan agama Islam terdapat esensi yang didapat, pertama, bagi dosen proses pembelajaran menuntut kreativitas dan inovasi serta metode yang lebih variatif dalam upaya untuk bisa mengaitkan materi pembelajaran dengan situasi dan kondisi mahasiswa dalam kehidupan sehari-hari.

Kedua, bagi mahasiswa dengan adanya penerapan pendekatan pembelajaran kontekstual, maka mahasiswa menjadi lebih aktif dan berpartisipasi aktif dalam setiap proses pembelajaran, mahasiswa merasa lebih tertantang dengan pembelajaran yang dilakukan, mahasiswa terdorong untuk mempelajari lebih jauh dengan mengkonstruks materi pembelajaran, sehingga proses pembelajaran lebih menyenangkan dan lebih bermakna serta teraplikasi bagi mahasiswa dalam kehidupan nyata.

Ketiga, membantu mahasiswa menemukan hubungan penuh makna antara ide-ide abstrak dengan penerapan praktis di dalam konteks dunia nyata. Mahasiswa dapat menginternalisasikan konsep melalui pengalaman belajar, penemuan, penguatan dan keterhubungan dalam setiap proses pembelajaran yang terjadi. Sehingga proses pembelajaran tidak hanya transfer ilmu pengetahuan yang bersifat surface learning semata, tetapi lebih dari itu proses pembelajaran bisa membuat mahasiswa untuk lebih bisa memahami, memaknai, dan mengaplikasikannya dalam kehidupan mereka sehari-hari atau pembelajaran 
secara deep learning.

\section{KESIMPULAN}

Penerapan pendekatan pembelajaran kontekstual dalam mata kuliah PAI terbukti dapat memberikan warna baru dalam proses pembelajaran yang dilakukan. Pembelajaran memfasilitasi mahasiswa untuk menghadirkan dunia nyata ke dalam kelas, dan memfasilitasi mahasiswa menemukan hubungan kebermaknaan antara pengetahuan yang dimiliki dengan penerapannya dalam kehidupan nyata.

Pembelajaran menjadi milik mahasiswa dan dapat menemukan makna esensial serta aktual dibalik materi yang teoretikal, ketika dalam proses pembelajaran mengisyaratkan ketercapaiannya komponen-komponen pembelajaran kontekstual, yaitu: cosnstructivism, inquiry, questioning, modelling, reflection, dan authentic assessment. Sehingga proses pembelajaran menjadi lebih fun, focus, fresh, and meaningful.

Penerapan pendekatan pembelajaran kontekstual terbukti dapat memberikan kontribusi yang positif sebesar 48,72\% dalam proses pembelajarannya. Proses pembelajaran PAI menjadi lebih variatif dan aplikatif, yang mengarahkan kepada pemahaman, pengertian yang mendalam, dan aplikasi nyata dari materi yang dipelajari, serta menghindari pembelajaran yang teoretis-abstrak yang bersipat verbalisme, sehingga hasil belajar mahasiswa menjadi meningkat dan lebih baik.

\section{REFERENSI}

Aqib, Z. (2013). Model-Model, Media, dan Strategi Pembelajaran Kontekstual (inovatif). Bandung: Yrama Widya.

Freire, P. (2008). Pendidikan Kaum Tertindas. Jakarta: Pustaka LP3ES
Indonesia.

Hamruni. (2012). Strategi Pembelajaran. Yogyakarta: Insan Madani.

Johnson, E. B. (2011). CTL: Contextual Teaching \& Learning: Menjadikan Kegiatan Belajar-Mengajar Mengasikan dan Bermakna, (terjemah Ibnu Setiawan). Bandung: Kaifa. (2002). Contextual Teaching and Learning: what it is and why it's here to stay. California: Corwin Press.

Komalasari, K. (2013). Pembelajaran Kontekstual Konsep dan Aplikasi. Bandung: PT Refika Aditama.

Lickona, T. (2004). Character Matters; How to Help Our Children Develop Good Judgment, Integrity, and Other Essential Virtues. New York: Touchstone.

(2013). Character Matters, Persoalan karakter; Bagaimana Membantu Anak Mengembangkan Penilaian yang Baik, Integritas, dan Kebajikan Penting Lainnya. Jakarta: Bumi Aksara.

Muslich, M. (2011). KTSP Pembelajaran Berbasis Kompetensi dan Kontekstual, Panduan bagi Guru, Kepala Sekolah, dan Pengawas Sekolah. Jakarta: Bumi Aksara.

Sanjaya, W. (2010). Strategi Pembelajaran Berorientasi Standar Proses Pendidikan. Jakarta: Prenada Media Group.

Schunk, D. H. (2012). Learning Theorries An Educational Perspective (TeoriTeori Pembelajaran: Perspektif Pendidikan). terjemah Eva Hamdiah, Rahmat Fajar. Edisi keenam, Yogyakarta: Pustaka Pelajar. 
(2012). Learning Theories An

Educational Perspective. Boston:

Pearson.

Slavin, R. E. (1994). Educational Psychology: Theory and Practice. Needhem Heights Massachusetts: Allyn and Bacon.

(2011). Psikologi Pendidikan Teori dan Praktik. Jakarta: Indeks.

Sugiyono. (2013). Metode Penelitian Pendidikan. Bandung: Alfabeta.

Tafsir, A. (2011). Metodologi Pengajaran Agama Islam. Bandung: PT. Remaja Rosda Karya. 